\title{
BOOKS HAVE THEIR STORIES: FROM MY HISTORY OF PHARMACY COLLECTION
}

\section{BY DAVID L. COWEN}

Professor David L. Cowen was a world-renowned scholar of the history of pharmacy.

There is a pleasure in book collecting that goes beyond merely getting another addition to put on the shelf. Books may have their own stories beyond their content, binding, or typography. It is the purpose here to illustrate the idea that books have interesting stories associated with them that have little, no, or serendipitous relationship to what is inside them.

Take for example, the story of my copy of the Pharmacopoeia Collegii Regii Medicorum Edinburgenis Reformata (Rotterdam: Beman, Bennett \& Hake, 1775), which begins with a note from a London friend who knew of my interest in the Edinburgh Pharmacopoeia. The book had been bought in a batch of books at an auction by a Harley Street surgeon, she wrote, and she gave me his name and address. A letter to the surgeon, offering to buy or trade, elicited the response that he was opposed to allowing British treasures to leave the country and fall into foreign hands. I responded that I had been born in New York, named for the Duke of York, raised in Newark, named for Newark on Trent, in New Jersey, named for the Isle of Jersey, in Essex County. My university began as Queen's College, named for Queen Charlotte, was located in New Brunswick, named for the Duke of Brunswick, in Middlesex County. "Think of me as a colonial, not a foreigner," I pleaded. I got the book. I must admit that I 
also added a note to the effect that this particular British treasure had been published in the Netherlands!

Then there was, and is, the mystery of the little Pharmacopoeia Collegii Regii Medicorum Edinburgensis that bears the imprint "Vindelicae: Typis T.J.Trattnern. M, DCC, LXXXVIII." Intensive research by me and two librarians failed to reveal a city that went by only "Vindelica." There was Vindelica Aelia Augusta, which became Augsburg, and the only other city that came close was Vindobona, which became Vienna. A note to the Österreichische Nationalbibliothek elicited this response: "Regarding the place of publication, we must say that 'Vindelica' certainly does not stand for Vienna. Our inclination is that Trattner had a branch in Augsburg." From the Bayerische Staatsbibliothek in Munich came an emphatic "We cannot accept the assumption that the place of publication, 'Vindelica,' stands for Augsburg. When one looks into the Orbis Latinus . . . and finds that Augsburg is indicated under the heading 'Vindelica Aelia Augusta,' one can easily fall into the error of thinking that 'Vindelica' alone stands for Augsburg. The publisher named, T. J. Trattner, can certainly be no other than the Viennese printerpublisher Johann Thomas von Trattner." Perhaps the solution is to be found in the added comment by the Österreichische Nationalbibliothek: "Another possibility is that Trattner chose "Vindelica" with intention of perpetuating a deception." One must also consider the possibility that Trattner was not involved at all and that some enterprising printer took the name of "T.J. Trattner " to give the appearance that the book was a publication of "J.T. Trattner" and gave a made-up but suggestive place of publication.

I had just purchased a sound replacement for, and was about to discard, a ragged, interleaved, and thoroughly-markedcopy of the fourth (1744) edition of the Edinburgh Pharmacopoeia, when I realized that what I was about to throw out was not just a scruffy book. It was a copy of the Pharmacopoeia that was used 


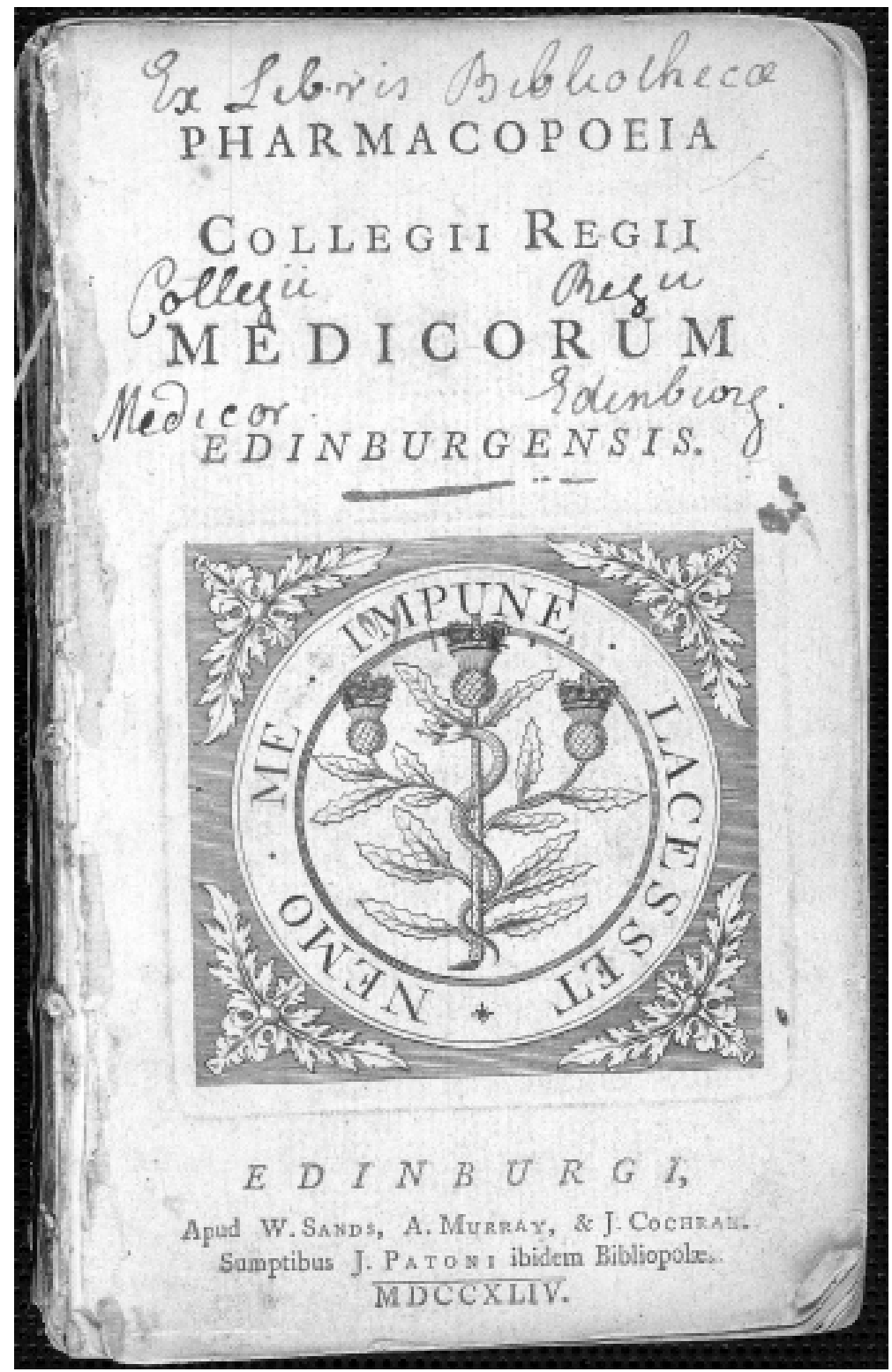

Figure 3.1

Title page of the heavily hand-annotated copy of the fourth edition of Royal College of Physicians of Edinburgh. Pharmacopoeia Collegii Regill Medicorum Edinburgensis. Edinburgi: W. Sands, A. Murrary, \& J. Cochran, MDCCXLIV [1744]. Cowen asserts that this copy was used to make revisions for the next edition 


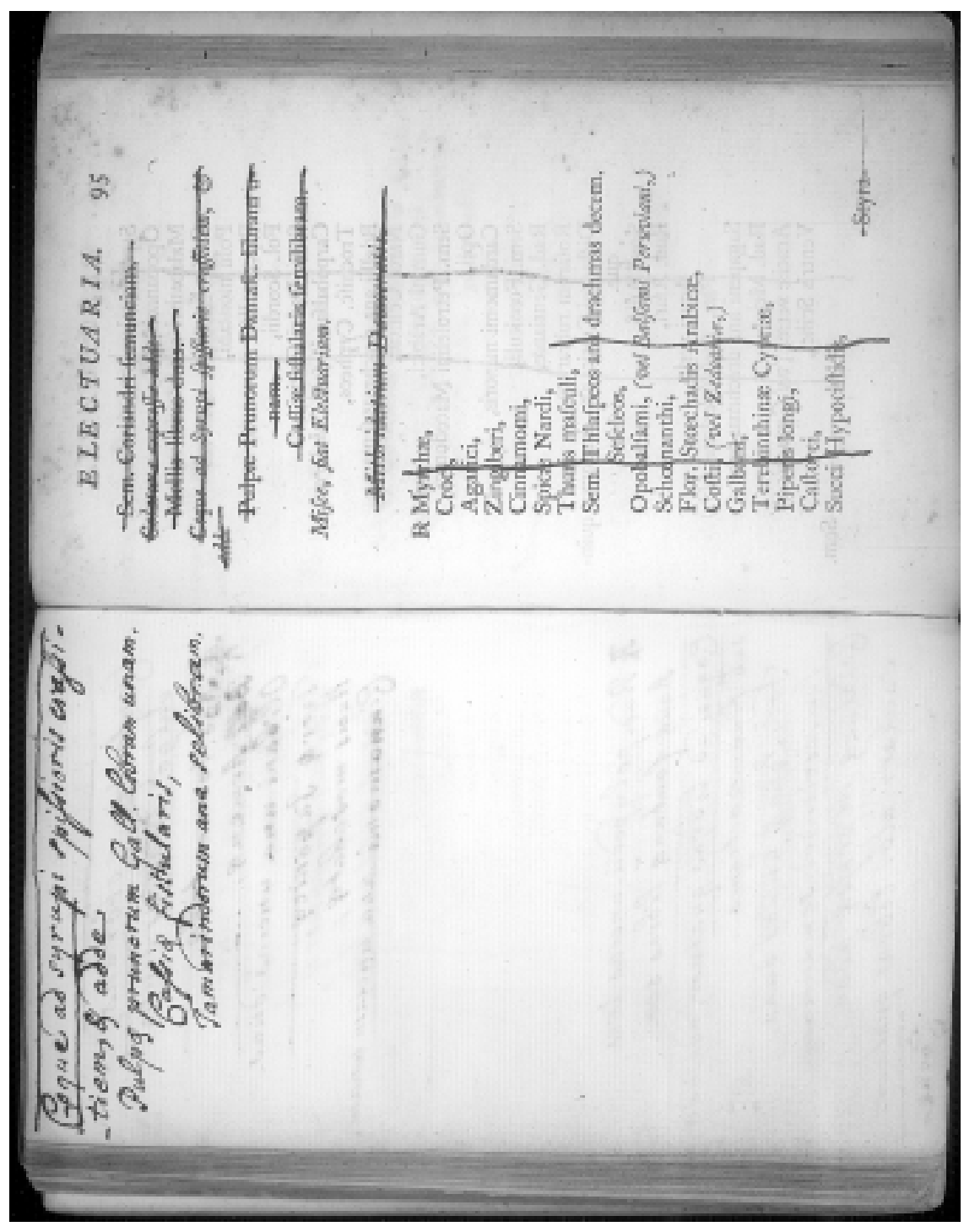

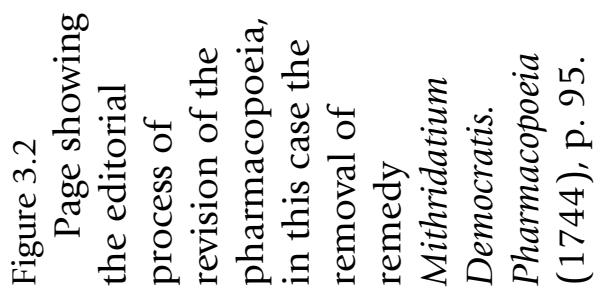


by a member of the Committee on the Pharmacopoeia at the Royal College of Physicians of Edinburgh charged with preparing the fifth edition of the work. There were a very great many deletions and additions that indicated the tremendous importance placed by the medical establishment in the materia medica-pharmacotherapy was, after all, the most important therapeutic system available. (The Royal College regularly updated its Pharmacopoeia-there were 12 editions between 1699 and 1841.) Most important, and, to me, thrilling, was that our committee member had deleted the traditional and ubiquitous polypharmaceuticals. It was indeed a great moment in the history of medicine and pharmacy when he drew two vertical lines through the theriacs (mixtures that purportedly were an antidote to poison), especially the Mithridatium Democratis. Imagine what must have been going through his mind when he deleted a remedy that had its origins with Mithradates VI, the first-centuryB.c. king of Pontus, and that had had a dominant place in the physician's armamentarium and the pharmacist's arcanum for seventeen centuries.

The theriacs were the preeminent of the polypharmaceuticals. The Mithridatium Democratis of the Edinburgh Pharmacopoeia contained a modest 50 or so ingredients; other formulas contained three or more times as many. The ingredients were mainly herbal, with opium being the most important, but from time to time castoreum (from the glands of the beaver), viper flesh, and skink were added. Each ingredient had to be measured precisely in small quantities, and the compounding of them by the chief apothecaries of the city under the observation of the local Collegium Medicum became public ceremonies with pomp and circumstance in the public square or in a public building. (The last such ceremony in Paris took place in 1790.)

It would be interesting to be able to trace the thought processes that were responsible for this (first by any pharmacopoeia) expunging of the theriacs. Certainly considerable 
influence must have come from William Heberden's powerful castigation of them in his Antitheriaca: An Essay on Mithridatium and Theriaca, published in London in 1745.

There are also stories told by books over and above their contents. Take the Connoisance pratique des medicamens . . . ou nouveau dispensaire ... par M. Lewis. A translation of William Lewis's New Dispensatory, it was twice published (in three volumes). The first issue was in 1775, the second in 1803 . Only the title pages differentiate the first from the second; the bodies of the books were identical. But more significant considerations were involved than the publishing practices of the time. The first of the issues bears the imprint "M. DCC. LXXV. Avec Approbation, et Privilege du Roi"; the second bears the imprint "An XI1803." The French Revolution changed the date; the content withstood the upheaval. Significant, too, was the fact that the French were issuing a translation of an English work in 1803, at a time when the French were threatening to invade England. Even war cannot stop the process of acculturation-or at least it did not impede the entrepreneurial acumen of publishers.

There is more to the story, however. The Connoisance copies the 1765 revision of Lewis. Lewis first appeared in 1753 and was first revised in 1765. (All four subsequent "editions" were the same as the 1765 "2nd edition.") The Connoisance claimed to be based on a 1756 edition. There was none, and the date was either a typographical error or another display of the entrepreneur's acumen to make the work seem more recentthan it was. In any case, the significant thing is that the work was a translation of the 1765 Lewis edition, ten years and then twentyeight more years after its original-an indication of the traditional basis of, and the scarcity of innovation in, the materia medica. Indeed, only one major innovation took place during this period-recognition of the importance of foxglove (digitalis) - but a good deal of pharmacopoeial cleansing that had taken place went unnoticed in the Connoisance. 
Perhaps an even more impressive story is told on the title page of De Sgobbis's Theatro Farmaceutico (first issued in 1667; the 1682 Venice issue is illustrated). It presents an artful and quick commentary not only on the state of medicine and pharmacy, but also on the intellectual and social milieu of the late seventeenth century. Center stage are eight figures: Hippocrates, Galen, Dioscorides, and Messue on the left, confronting Paracelsus, Arnold of Villanova, Hermes Trismegistus, and Jan Baptista van Helmont on the right. These represented the schools of thought that had been contending for medical preeminence since about 1500, those favoring the largely herbal, humoral pathology of Galen on the left and those favoring the chemiatric approach of Paracelsus on the right. That medicine and pharmacy had eventually embraced both is evident by the legend at the top of the medicine cabinet (unfortunately too small to see): "Medicamenta Spagrici et Galenica." But there is more that the title page tells us of the materia medica of the age. There are a few herbs to be seen, and a few animals and fish, and a ship suggestive of the plant-based drugs that came from American and East Indian sources, but most interesting is the prominence given, at the left, to mining. Alum, antimony, silver, gold, arsenic, lead, sulfur, and especially quicksilver (mercury) were among the minerals to be found in the pharmacopoeias of the time. (For example, they were among the more than 50 "Minerals, Metals, \& Stones" in the Pharmacopoeia Bruxellensis of 1641.)

But there is more on the page than the description of the pharmacy of the seventeenth century. The two gooselike figures at the upper corners are labeled, freely translated, "I prevail" on the left, and "Do no harm" on the right-Hippocratic ideas. On the proscenium arch, however, contemporary concepts are depicted: from the top, the figures are labeled rest, wisdom, and science on the left, and health, art, and prudence on the right. The figures at the bottom, from the left, represent theory, justice, 
physics, nature, experience, and practice. And the four small, encircled vignettes represent study, industry, labor, and vigilance. This is indeed an artistic epitome of the Age of Enlightenment. 